\title{
Satellite tracking of juvenile whale sharks in the Sulu and Bohol Seas, Philippines
}

\author{
Gonzalo Araujo ${ }^{\text {Corresp.. }}{ }^{1}$, Christoph A Rohner ${ }^{2}$, Jessica Labaja ${ }^{1}$, Segundo J Conales ${ }^{3}$, Sally J Snow ${ }^{1}$, Ryan \\ Murray ${ }^{1}$, Simon J Pierce ${ }^{2}$, Alessandro Ponzo ${ }^{1}$ \\ ${ }^{1}$ Large Marine Vertebrates Research Institute Philippines, Jagna, Bohol, Philippines \\ 2 Marine Megafauna Foundation, Truckee, California, United States \\ 3 Tubbataha Management Office, Puerto Princesa City, Palawan, Philippines \\ Corresponding Author: Gonzalo Araujo \\ Email address: g.araujo@lamave.org
}

The whale shark Rhincodon typus was uplisted to 'Endangered' in the 2016 IUCN Red List due to $>50 \%$ population decline, largely caused by continued exploitation in the IndoPacific. Though the Philippines protected the whale shark in 1998, concerns remain due to continued take in regional waters. In light of this, understanding the movements of whale sharks in the Philippines, one of the most important hotspots for the species, is vital. We tagged 17 juvenile whale sharks with towed SPOT5 tags from three general areas in the Sulu and Bohol Seas: Panaon Island in Southern Leyte, northern Mindanao, and Tubbataha Reefs Natural Park (TRNP). The sharks all remained in Philippine waters for the duration of tracking (6-126 days, mean 64). Individuals travelled 86-2,580 km (mean $887 \mathrm{~km}$ ) at a mean horizontal speed of $15.5 \pm 13.0$ SD km day ${ }^{-1}$. Whale sharks tagged in Panaon Island and Mindanao remained close to shore but still spent significant time off the shelf ( $>200$ m). Sharks tagged at TRNP spent most of their time offshore in the Sulu Sea. Three of twelve whale sharks tagged in the Bohol Sea moved through to the Sulu Sea, whilst two others moved east through the Surigao Strait to the eastern coast of Leyte. One individual tagged at TRNP moved to northern Palawan, and subsequently to the eastern coast of Mindanao in the Pacific Ocean. Based on inferred relationships with temperature histograms, whale sharks performed most deep dives (>200 m) during the night, in contrast to results from whale sharks elsewhere. While all sharks stayed in national waters, our results highlight the high mobility of juvenile whale sharks and demonstrate their connectivity across the Sulu and Bohol Seas, highlighting the importance of the area for this endangered species. 
1 Satellite tracking of juvenile whale sharks in the Sulu and Bohol Seas, Philippines

2 Gonzalo Araujo $^{1}$, Christoph A. Rohner ${ }^{2}$, Jessica Labaja ${ }^{1}$, Segundo J. Conales ${ }^{3}$, Sally J. Snow ${ }^{1}$,

3 Ryan Murray ${ }^{1}$, Simon J. Pierce ${ }^{2}$, Alessandro Ponzo ${ }^{1}$

4

5 Affiliations

$6{ }^{1}$ Large Marine Vertebrates Research Institute Philippines, Jagna, Bohol, Philippines

$7 \quad{ }^{2}$ Marine Megafauna Foundation, Truckee, California, USA

$8{ }^{3}$ Tubbataha Management Office, Puerto Princesa, Palawan, Philippines

9

\section{Corresponding Author}

11 Gonzalo Araujo

12 g.araujo@lamave.org |+639054043833

13 


\section{Abstract}

16 The whale shark Rhincodon typus was uplisted to 'Endangered' in the 2016 IUCN Red List due 17 to $>50 \%$ population decline, largely caused by continued exploitation in the Indo-Pacific.

18 Though the Philippines protected the whale shark in 1998, concerns remain due to continued 19 take in regional waters. In light of this, understanding the movements of whale sharks in the 20 Philippines, one of the most important hotspots for the species, is vital. We tagged 17 juvenile 21 whale sharks with towed SPOT5 tags from three general areas in the Sulu and Bohol Seas:

22 Panaon Island in Southern Leyte, northern Mindanao, and Tubbataha Reefs Natural Park 23 (TRNP). The sharks all remained in Philippine waters for the duration of tracking (6-126 days, 24 mean 64). Individuals travelled 86-2,580 km (mean $887 \mathrm{~km}$ ) at a mean horizontal speed of 15.5 $25 \pm 13.0 \mathrm{SD} \mathrm{km} \mathrm{day}^{-1}$. Whale sharks tagged in Panaon Island and Mindanao remained close to 26 shore but still spent significant time off the shelf $(>200 \mathrm{~m})$. Sharks tagged at TRNP spent most of 27 their time offshore in the Sulu Sea. Three of twelve whale sharks tagged in the Bohol Sea moved 28 through to the Sulu Sea, whilst two others moved east through the Surigao Strait to the eastern 29 coast of Leyte. One individual tagged at TRNP moved to northern Palawan, and subsequently to 30 the eastern coast of Mindanao in the Pacific Ocean. Based on inferred relationships with 31 temperature histograms, whale sharks performed most deep dives $(>200 \mathrm{~m})$ during the night, in 32 contrast to results from whale sharks elsewhere. While all sharks stayed in national waters, our 33 results highlight the high mobility of juvenile whale sharks and demonstrate their connectivity 34 across the Sulu and Bohol Seas, highlighting the importance of the area for this endangered 35 species. 
39

40

41

42

43

44

45

46

47

48

49

50

51

52

53

54

55

56

57

58

59

60

61

62

63

64

65

66

67

The whale shark Rhincodon typus is the world's largest fish. The species inhabits tropical and sub-temperate waters, with seasonal aggregations across their range, usually associated with high prey availability (e.g. copepods, Motta et al., 2010; sergestids, Rohner et al., 2015; coral spawn, Holmberg et al., 2008). Most coastal aggregations are dominated by juvenile male sharks (Norman et al., 2017), although Cochran et al. (2016) reported the first known juvenile 1:1 male to female aggregation in the Red Sea. Recent observations from the Galapagos, Qatar, St Helena and Baja California (Hearn et al., 2016; Robinson et al., 2017; Clingham et al., 2016; RamirezMacias et al., 2017) have highlighted that adult sharks are likely to have more pelagic habitat preferences than juveniles.

Work by Vignaud et al. (2014) suggested that whale sharks are genetically homogenous within the Indo-Pacific. However, photographic-identification (henceforth photo-ID) data from the global online database at Wildbook for Whale Sharks (www.whaleshark.org) has revealed little connectivity among Indo-Pacific aggregation sites over short- to medium-term timescales $(\sim 20$ years), with few demonstrated movements between non-contiguous feeding areas (Norman et al. 2017). While satellite telemetry studies have found whale sharks regularly cross international boundaries (Ecker et al., 2002; Tyminski et al., 2015; Robinson et al., 2017; Rohner et al., 2018), photo-ID data show that juvenile sharks, in particular, often have a high inter-annual site fidelity to specific feeding areas (Norman et al. 2017).

7 The Philippines is a global hotspot of whale shark abundance, and the associated whale shark tourism industry is important to the local economy. Whale shark tourism in the Philippines started in Donsol, Sorsogon Province, where whale sharks aggregate seasonally (Nov-Jun) to feed (Pine et al., 2007; Quiros, 2007). Donsol now receives up to 27,000 tourists per season and, through dedicated photo-ID, over 500 individual sharks have been identified to date (Wildbook for Whale Sharks, May 2018). Provisioning-based tourism activity arose in late 2011 at Oslob, Cebu Province, which now attracts over 182,000 tourists a year, making it the largest whale shark watching destination in the world (Thomson et al., 2017). Over 350 individuals have been identified at the site, where whale sharks are hand-fed daily through the year, since photo-ID started in March 2012 (Wildbook for Whale Sharks, May 2018). Around 1,000 tourists visit Panaon Island, Southern Leyte Province, per season to swim with the non-fed sharks in this area 
68 (Araujo et al., 2017). Over 250 individuals have been identified at this site, typically associated 69 with localised zooplankton blooms that occur between October and June (Wildbook for Whale 70 Sharks, May 2018). Araujo et al. (2014; 2016a) elaborate on the connectivity between sites in the 71 Bohol Sea through photo-ID at dedicated study sites and through citizen science contributions, 72 though little connectivity has been observed between these areas and Donsol $(<1 \%$ of identified 73 sharks) or Tubbataha Reefs Natural Park (TRNP) in the Sulu Sea (also $<1 \%$ ). Through citizen 74 science contributions and opportunistic research effort, over 74 individuals have been identified 75 to date at TRNP (Wildbook for Whale Sharks, May 2018).

76 Whale sharks were targeted by fisheries in the Philippines, before national protection in 1998 77 (Alava et al., 2002), and in Taiwan into the mid 2000s (Hsu et al., 2007). An estimated 1,000 78 whale sharks were reportedly landed yearly in Hainan Province, China, alone (Li et al., 2012).

79 Pronounced declines in sightings and catches prompted the inclusion of the species under 80 Appendix II of the Convention on International Trade in Endangered Species of Wild Fauna and 81 Flora (CITES) in 2002, an 'Endangered' classification on the IUCN Red List of Threatened 82 Species in 2016 (Pierce \& Norman, 2016), and a listing on Appendix I of the Convention on 83 Migratory Species (CMS) in 2017. While these conservation tools can be effective for 84 85 conserving elasmobranchs (Simpfendorfer \& Dulvy, 2017), implementation and enforcement of regulations often vary between countries ( $\mathrm{Li}$ et al. 2012), posing challenges for a highly mobile species like the whale shark.

87 International movements between Taiwan and the Philippines have been identified, through 88 satellite telemetry and photo-ID (Hsu et al., 2007; Araujo et al., 2016a), and between the 89 Philippines and Vietnam through satellite tracking (Eckert et al., 2002). The relatively close 90 proximity of the Philippines to whale shark aggregations in adjacent countries (e.g.

91 Cenderawasih Bay, Indonesia, Himawan et al, 2015), and to the major fishery in the South China 92 Sea (Li et al., 2012), mean that understanding whale shark movements in the Philippines and 93 Southeast Asia is essential to support effective conservation efforts on a regional level. Here, we 94 used tethered, near-real-time satellite tags to explore the movements of juvenile whale sharks 95 tagged in the Bohol and Sulu Seas to evaluate inter-site connectivity and identify potential 96 anthropogenic threats that may affect sharks in this area. 


\section{Methods}

99 All work was performed in collaboration with the respective Regional Offices of the Department

100 of Environment and Natural Resources, the Department of Agriculture-Bureau of Fisheries and

101 Aquatic Resources and the Palawan Council for Sustainable Development (Wildlife Gratuitous

102 Permit 2017-13). All research in Tubbataha Reefs Natural Park was done in collaboration with

103 the Tubbataha Management Office.

104 Study Sites

105 Whale sharks were tagged at three different locations (Fig. 1, 2, 3): (a: "Panaon Island") Panaon

106 Island has had ongoing whale shark tourism since 2006, and dedicated research since 2013

107 (Araujo et al., 2016a). The whale shark 'season' is highly variable, with sightings reported

108 anytime between October and June (Araujo et al., 2017). (b: "Mindanao") Misamis Oriental and

109 Surigao del Norte in northern Mindanao were chosen as tagging locations following reports by

110 fisherfolk on the occurrence of whale sharks in the area. Few data are available from this region,

111 though whale shark hunters once operated from Talisayan in Misamis Oriental and in Salay,

112 where 100 individuals were landed per year in the 1990's (Alava et al., 2002), and where Eckert

113 et al. (2002) tagged two whale sharks in 1997. Both tagging sites are within the Bohol Sea, a rich

114 ecosystem that reaches $>2,000 \mathrm{~m}$ depth and hosts 19 species of cetaceans (Ponzo et al., 2011),

115 marine turtles (Quimpo, 2013; Araujo et al., 2016b), five species of mobulid rays

116 (Rambahiniarison et al., 2016), and in which whale shark movements have been confirmed

117 through photo-ID (Araujo et al., 2014; 2016a). (c: “TRNP”) Tubbataha Reefs Natural Park

118 (TRNP) has been an offshore no-take marine protected area (MPA) since 1988 and a UNESCO

119 World Heritage Site since 1993. Whale sharks were historically encountered occasionally in the

120 park. There was a substantial increase in the number of sightings in 2014, and the site was

121 selected as an additional tagging location.

\section{Photo-ID}

123 Opportunistic whale shark surveys were conducted from small outrigger pumpboats within $1 \mathrm{~km}$

124 from shore at Panaon Island and Mindanao. Upon encountering a whale shark, a researcher

125 entered the water and photographed the left flank of the animal, above the pectoral fin and

126 behind the gill slits, to identify the individual (see Arzoumanian et al., 2005). The sex of the 
127 animal was confirmed by the presence (male) or absence (female) of claspers in the pelvic

128 region. Size was estimated relative to an object of known length, such as swimmers or boats.

129 Whale shark identification images were then visually checked against a site-specific database

130 and subsequently run through the offline identification software $\mathrm{I}^{3} \mathrm{~S}$ (http://www.reijns.com/i3s;

131 Van Tienhoven et al., 2007) containing the same database. Newly identified individuals were

132 uploaded onto the online database Wildbook for Whale Sharks (www.whaleshark.org) to assess

133 global connectivity. Whale sharks were encountered on SCUBA at TRNP. Dive teams of two or

134 three researchers drifted with the current at c. $15 \mathrm{~m}$ depth. Upon encountering a whale shark, the 135 animal was photo-identified, sexed and sized as described above.

136

137 Tagging

138 Wildlife Computers SPOT5 satellite tags (www.wildlifecomputers.com) were used to track the 139 movement of 17 whale sharks. Tags were tethered on a $1.8 \mathrm{~m}$ long, $3 \mathrm{~mm}$ thick $(240 \mathrm{~kg}$ breaking 140 strain) Dyneema line. The line was attached to a titanium dart (45 x 14 x $1.3 \mathrm{~mm}$ ), which was 141 inserted 10-20 cm into the subdermal tissue below the dorsal fin using a Hawaiian sling. The 142 tags' positive buoyancy then allowed transmission to the ARGOS satellite system when the 143 shark was near the surface and the tag was exposed to air. Daily transmissions were limited to 144250 to maximise battery life ( $>180 \mathrm{~d})$. Tags were deployed in Panaon Island in April and 145 November 2015, and in Mindanao in March and April 2016 (Table 1), corresponding with 146 known seasonality at these sites (see above). Tags at TRNP were deployed in May 2015 based 147 on regular sightings during the tourist season (March to June). No antifouling agent was used on 148 the tags due to a lack of availability.

\section{Horizontal movements}

151 Tag location transmissions have a location class (lc: 3, 2, 1, 0, A, B, Z, in decreasing order of 152 accuracy) associated with them. Locations transmitted before tag deployment, and after the tag 153 detached and floated, were removed. The latter situation was detected through transmission of 154 constant temperature histograms and early morning transmissions (00.00-03.00 hh) over five 
155 consecutive days (Hearn et al. 2013). Locations on land (10.7\% of total transmissions) were 156 removed by extracting bathymetry data from the ETOPO dataset (Amante \& Eakins, 2009) for 157 each location, using the xtractomatic package in $\mathrm{R}$ (Mendelssohn, 2017). The bulk of remaining 158 transmissions (69\%) were from the less precise lc: B and A. The Douglas filter (Douglas et al., 159 2012) was applied to evaluate the most probable track. The filter removed unrealistic locations 160 based on the error associated with the ARGOS location class. The filter was set to include all 161 locations with a $1 \mathrm{c} \geq 1$ and used the maximum redundant distance (MRD) method (Douglas et al., 162 2012) with a maximum redundancy of $10 \mathrm{~km}$. The filter removed 158 locations $-14 \%$ of the 163 data - but kept some B and A locations that had a relatively larger error radius. The filtered 164 tracks were used in all subsequent analyses. Tracks were plotted in QGIS (QGIS Development 165 Team, 2017; http://qgis.osgeo.org) and track distances calculated as the sum of straight-line 166 horizontal distances between consecutive locations, therefore representing the minimum possible 167 distance the sharks swam. No interpolation was done.

168

Time-at-temperature histograms

170 Tags recorded temperature in 12 pre-defined bins, $<0^{\circ} \mathrm{C}, 0-5^{\circ} \mathrm{C}, 5-10^{\circ} \mathrm{C}, 10-15^{\circ} \mathrm{C}$ and then every $1712.5^{\circ} \mathrm{C}$ between $15^{\circ} \mathrm{C}$ and $32.5^{\circ} \mathrm{C}$, and $>32.5^{\circ} \mathrm{C}$. The temperature was measured every $10 \mathrm{~s}$ and 172 integrated over two time periods per day (night $=18: 00-6: 00$; day $=6: 00-18: 00$ ). These bins 173 were used to calculate time-at-temperature (TAT) histograms. There were gaps in the TAT 174 timeseries because tags only transmitted data on 39\% of tracking days overall. Those gaps were 175 not plotted, and therefore the x-axes of TAT plots are chronological but not continuous.

\section{Results}

\section{Photo-ID}

179 All 5 sharks tagged at TRNP (Table 2) were new to the Philippine database at the time of 180 tagging. Only one (P-813) was resighted at TRNP, the day after tagging, by a citizen scientist 181 (Wildbook for Whale Sharks, February 2018). Two of the whale sharks tagged in Mindanao (P182791 and P-926) were first identified in Panaon Island in March and December 2015, respectively. 
183 No other tagged whale sharks in Mindanao were resighted. Individual P-491 was first identified

184 in Panaon Island in February 2013 and was resighted in December 2015 (post-tagging). P-493

185 was first identified in Panaon Island in March 2013 and was resighted again in Panaon Island in

186 November and December 2015, following tag detachment in June of that year. Shark P-430 was

187 first identified in Oslob, Cebu, in March 2012. The shark was highly resident to the provisioning

188 site (see Araujo et al., 2014), and was subsequently first identified at Panaon Island when it was

189 tagged in April 2015. The shark was resighted back at Oslob in July 2016, and last seen in

190 Panaon Island in November 2017. Individual P-532 was first identified in Panaon Island in

191 March 2013 and tagged on November 16 ${ }^{\text {th }} 2015$. The shark was resighted there again in January

1922016 following tag detachment. Whale shark P-904 was tagged when first identified in

193 November 2015 and subsequently resighted tethering the tag in December 2015. The other 2

194 whale sharks tagged in Panaon Island were not resighted again.

195

196 Tagging, track duration and distances

197 Tagged whale sharks were all juveniles, with a mean estimated length of $5.6 \mathrm{~m}( \pm 0.7 \mathrm{~m}$ S.D.)

198 and ranging from 4.5 to $7 \mathrm{~m}$ (Table 1). Most of the tagged sharks were males (73\%). Whale

199 sharks at Mindanao and TRNP were not resighted post-tagging, but three individuals were

200 resighted at Panaon Island while the tags were still attached. No obvious tagging-related damage

201 was observed on the animals (GA, pers. obs). Tracks ranged from 6-126 days, with a mean \pm SD

202 of $64 \pm 35 \mathrm{~d}$. The tags transmitted locations on $39 \%$ of possible days, with a mean of 25

203 transmitting days per track, and a mean 2.2 transmissions per transmitting day. Whale shark

204 track lengths ranged from 86 to $2,580 \mathrm{~km}$ in length, with a mean of $887 \mathrm{~km}$. Mean horizontal

205 speed was $15.5 \mathrm{~km} \mathrm{day}^{-1}$.

206

Horizontal movements

207 All whale sharks stayed in the Philippines over the tracking duration. None had been

208 subsequently identified in other countries as of February 2018. Seven sharks tagged at Panaon

209 Island transmitted most frequently from around the tagging location (Fig. 1). Two sharks (P-904

210 and P-905) moved into the central Sulu Sea after having been tagged on consecutive days. Four

211 of the Panaon Island sharks crossed the nearby Surigao Strait to the eastern coast of Leyte Island, 
212 and south of Siargao Island. Whale sharks tagged off Mindanao transmitted most frequently from

213 the southern Bohol Sea, and none crossed the Surigao Strait (Fig. 2). One of the five sharks (P-

214 970) swam into the Sulu Sea, while two others crossed the Bohol Sea, with P-926 swimming to

215 Sogod Bay in Southern Leyte, and P-971 swimming to Bohol (Fig. 2). Whale sharks tagged at

216 TRNP stayed in the Sulu Sea, with the exception of P-813 that transmitted from northern

217 Palawan and then lost its tag in the Pacific Ocean off eastern Mindanao following 20 days of no

218 transmissions (Fig. 3). Temperature histograms going back to six days prior to tag detachment

219 clearly indicate that this tag was still attached to the shark while it was in transit, but the tag did

220 not transmit a location over that period. We assume the shark swam through the Sulu and Bohol

221 Seas into the Pacific. Sharks did not spend extended periods of time within the TRNP, with most

222 locations transmitted from the shelf in the north of Palawan and from the shelf edge off Borneo

223 within the Sulu Sea (Fig. 3).

224

225 Time-at-temperature

226 There were 970 time-at-temperature records for all tags combined. Sharks utilised all

227 temperature bins excepting the coldest $\left(<0^{\circ} \mathrm{C}\right)$. Whale sharks spent the majority $(74.2 \%)$ of their

228 time in $25-30^{\circ} \mathrm{C}$ water, followed by the $30-32.5^{\circ} \mathrm{C}(11.6 \%)$ bin (Fig. 4). Overall, $5.8 \%$ of their

229 time was spent in $<20^{\circ} \mathrm{C}$, but there were marked diurnal differences. Sharks only spent $2.1 \%$ of

230 the daytime in colder water $\left(<20^{\circ} \mathrm{C}\right)$, but this increased to $9.6 \%$ at night (Fig. 4$)$.

231 Vertical movements, as inferred from TAT time-series, varied widely among individuals (Sup.

232 Figures for all plots). Broadly, sharks spent more time at cooler temperatures when they were off

233 the continental shelf, and during the night rather than during the day. As an example, shark P-

234818 (Fig. 5) was tagged in TRNP, and spent the first 4 weeks in the central Sulu Sea where it

235 regularly dived into deeper (cooler) water, especially at night. It then spent the next three months

236 at the continental shelf edge and on the shelf off Borneo, where ventures into cooler temperatures

237 were infrequent (Fig. 5).

238 Bathymetric depth at transmission locations ranged from 1-8, $739 \mathrm{~m}$ depth. $26 \%$ of all locations

239 came from shallow shelf waters, $<200 \mathrm{~m}$ deep. $34 \%$ of all locations were from locations over 
$240>1,000 \mathrm{~m}$ depth. Regional differences were observed, with $20 \%$ of locations from shelf waters

241 for sharks tagged at Panaon Island, compared to 29\% from both Mindanao and TRNP sharks.

243 Discussion

244 The tagged juvenile whale sharks all remained within the Philippines over the duration of 245 tracking. They were, however, highly mobile, moving between the Sulu and Bohol Seas, and 246 between the Sulu Sea and Pacific Ocean. Although juveniles had an affinity to coastal areas, they 247 still spent $74 \%$ of their time offshore over deep water $>200 \mathrm{~m}$. Some whale sharks displayed 248 both short-term site fidelity to their respective tagging areas, with transmissions received over 249 consecutive days following tagging, and longer-term site fidelity was also demonstrated through 250 photo-ID for some individuals. While national protection in the Philippines reduces the risk of 251 direct anthropogenic threats to these sharks, a lack of information on female and mature sharks 252 makes the population-level connectivity of whale sharks in Southeast Asia difficult to ascertain 253 without the aid of other techniques, such as genetics and genomics.

\section{Broad-scale habitat use}

255 Whale sharks tagged in Panaon Island spent consecutive weeks in the surrounding area, with two 256 sharks swimming to Mindanao and/or Bohol before returning to the site. Photo-ID has previously 257 shown that whale sharks reside a mean c. 27 days at Panaon Island, Southern Leyte (Araujo et 258 al., 2016a) highlighting its importance as a habitat for the species. Whale sharks' use of the 259 Bohol Sea may relate to primary productivity (Thomson et al., 2017). Three whale sharks tagged 260 in the Bohol Sea moved west into the Sulu Sea. A further two moved east to the eastern coast of 261 Leyte and through the Surigao Strait. Although these movements occurred in April and May, 262 when regional productivity typically remains relatively high (Cabrera et al., 2011; Stewart et al., 263 2017), the broad movement of these sharks suggests they were searching for further foraging 264 opportunities in surrounding areas.

265 TRNP comprises two atolls and a smaller reef system, all of which are adjacent to deep oceanic 266 waters. Individual P-970 (6.5 m female), originally tagged in Mindanao, transmitted from TRNP

267 before making an almost complete change in direction of travel, swimming back towards 
268 Mindanao when the tag detached. Through photo-ID and citizen science contributions, which are

269 high during TRNP's tourism season between March and June, it appears that whale sharks are

270 transient to TRNP as they are rarely resighted within the same season (Wildbook for Whale

271 Sharks, May 2018). The presence of whale sharks at TRNP could be linked to foraging - or

272 cleaning, as has been documented in Malpelo Island, Colombia (Quimbayo et al., 2017) - though

273 neither activity has been reported to date, despite the consistent presence of liveaboard dive

274 vessels. It is plausible that TRNP is used as a navigational waypoint by whale sharks travelling

275 through the Sulu Sea, as previously suggested by Acuña-Marrero et al. (2014) for Darwin Arch

276 in the Galapagos Islands. The TRNP atolls rise from deep water $(4,000 \mathrm{~m}<15 \mathrm{~km}$ from shore)

277 and, together with the Cagayancillo Islands, represent some of the only land masses between

278 Mindanao, Negros Island, and Palawan Island. Although the whale shark's ability to navigate

279 using the earth's magnetic fields remains poorly-understood, it has been explored in other

280 species (Rowat and Brooks, 2012), and it has been suggested as a possible driver of extreme

281 dives in whale sharks (>1,000 m; Brunnschweiler et al., 2009; Tyminski et al., 2015). However,

282 this phenomena, and the reason for their occurrence at TRNP, remain unclear.

283 Whale sharks spent little time $(5.8 \%)$ in cooler $\left(<20^{\circ} \mathrm{C}\right)$ waters. The majority of their time was 284 spent in the epipelagic zone based, on time-at-temperature (TAT) recordings. The Sulu Sea 285 reaches a min. temperature of $9.9^{\circ} \mathrm{C}$ at $\sim 400 \mathrm{~m}$, slightly cooler than the Bohol Sea's $11.6^{\circ} \mathrm{C}$ 286 (Gordon et al., 2011). Whale sharks' TAT histograms show they dived into these cooler waters 287 most frequently during the night, a reverse of the pattern observed in Mozambican whale sharks 288 (Rohner et al., 2018). Dives in the upper few hundred meters are likely to relate to foraging, as 289 whale sharks are thought to feed on meso- and bathypelagic zooplankton and fishes (Graham et 290 al., 2006; Brunnschweiler et al., 2009; Rohner et al., 2013). These prey species undergo daily 291 vertical migrations, staying in dark waters at depth during the day and moving towards the 292 surface during the night to forage (Brierley, 2014). Broadly sympatric mobulid capitalise on this 293 behaviour and forage on euphausiids in the Bohol Sea during the night near the surface (Rohner 294 et al., 2017). Why whale sharks appear to display a reverse pattern is unclear, and could benefit 295 from a specific investigation through the use of archival tags capable of recording temperature 296 and depth time series, as well as body position and acceleration, to provide more information on 297 their behaviour. 
300 Recent tracking evidence from Baja California revealed preference by juveniles to coastal areas, 301 whereas adults might have a stronger association with offshore habitats (Ramirez-Macias et al., 302 2017), supporting observations by Ketchum et al. (2013). Whilst this would support the general 303 understanding as to why coastal aggregations are mostly juvenile dominated (Rowat \& Brooks, 304 2012), the nature of why juveniles use offshore habitats warrants further investigation. Juveniles 305 tagged at TRNP, located at least $150 \mathrm{~km}$ from the nearest major landmass, spent most of their 306 time offshore. Contrastingly, whale sharks in Donsol, a mostly mature aggregation (53\% of 307 males are mature) and where whale shark pups were seen (Aca \& Schmidt, 2011), are found in 308 coastal and shallow waters seasonally, displaying strong inter-annual philopatry to the site 309 (McCoy et al., in review). Juveniles in the present study did spend part of their time in the open 310 ocean, as observed elsewhere (e.g. Robinson et al., 2017), suggesting whale sharks use different

311 habitats regardless of developmental stage and are perhaps more influenced by foraging 312 opportunities not fitting the traditional 'shark nursery' concept for juveniles (Heupel, Carlson \& 313 Simpfendorfer, 2007), which likely occurs at the neonate stage for whale sharks (Rowat \& 314 Brooks, 2012).

\section{Conclusions and conservation implications}

317 Satellite tagging of juvenile whale sharks in the Sulu and Bohol Seas has shed light into their 318 short-term habitat use, over a mean of 64 days. The Sulu and Bohol Seas are an important habitat 319 for whale sharks, with over 500 individuals identified to date in this region (Wildbook for Whale 320 Sharks, February 2018) and where >700 individuals were harvested between 1991 and 1997

321 (Alava et al., 2002). These Seas fall under the Sulu-Sulawesi Marine Ecoregion and are central to 322 the Coral Triangle Initiative (Secretariat, CTI, 2009; ADB, 2011). Therefore, identification of 323 threats and mitigation strategies here must be a conservation priority for the species given the 324 historical and present population-level threats in the region, in line with the Convention on 325 Migratory Species of the United Nations Concerted Actions for whale sharks passed in October 3262017 (UNEP/CMS/Concerted Action 12.7, 2017). 
328 This study has shown that juvenile sharks move quickly and widely through the Bohol and Sulu

329 seas. Further work is underway to elucidate presence, seasonality and contemporary threats to

330 whale sharks in the north Sulu Sea and southern Bohol Sea to complement the results presented

331 herein. Targeted whale shark fisheries existed in these areas into the 1990s. Coupled with the

332 Chinese fisheries operating in the broader region, and the established connectivity between the

333 Philippines and Taiwan, it is imperative to monitor this population as a whole to understand if

334 this population is in recovery, or continuing to decline. We recommend the use of longer-term

335 satellite telemetry and molecular tools to address this key knowledge gap in Southeast Asia, and

336 to strengthen international collaboration between and within East Asian and CTI countries.

\section{Acknowledgments}

339 We would like to thank Mrs Angelique Songco and the Park Rangers for their collaboration and 340 support while in TRNP. We would like to thank the Local Government Units and local 341 communities of Cagayancillo, Talisayan, Malimono, Pintuyan and San Ricardo. CAR and SJP

342 thank Marine Megafauna Foundation staff and volunteers for their assistance. We would like to 343 extend our gratitude to Jake Levenson, Steve De Neef and the Pintuyan People's Organization 344 "KASAKA" who helped with the overall success of this project. We thank the Editor and three 345 anonymous reviewers for their comments on the manuscript, which have strengthened our paper.

\section{References}

348 Acuña-Marrero D, Jiménez J, Smith F, Doherty JPF, Hearn A, Green JR \& Salinas-de-León P. 349 2014. Whale Shark (Rhincodon typus) Seasonal Presence, Residence Time and Habitat Use at 350 Darwin Island, Galapagos Marine Reserve. PloS One, 9(12), e115946.

351 Asian Development Bank. 2011. Comprehensive action plans of the Sulu-Sulawesi Marine 352 Ecoregion: A priority seascape of the Coral Triangle Initiative. Mandaluyong City, Philippines: 353 Asian Development Bank. 
354 Amante C \& Eakins BW. 2009. ETOPO1 1 Arc-Minute Global Relief Model: Procedures, Data 355 Sources and Analysis. NOAA Technical Memorandum NESDIS NGDC-24. National

356 Geophysical Data Center, NOAA. doi:10.7289/V5C8276M.

357 Andrzejaczek S, Meeuwig J, Rowat D, Pierce S, Davies T, Fisher R, Meekan M. 2016. The 358 ecological connectivity of whale shark aggregations in the Indian Ocean: a photo-identification 359 approach. Royal Society Open Science; 3(11):160455.

360 Araujo G, Lucey A, Labaja J, So CL, Snow S, Ponzo A. 2014. Population structure and 361 residency patterns of whale sharks, Rhincodon typus, at a provisioning site in Cebu, Philippines. 362 PeerJ, 2, e543.

363 Araujo G, Snow S, So CL, Labaja J, Murray R, Colucci A, Ponzo A. 2016a. Population 364 structure, residency patterns and movements of whale sharks in Southern Leyte, Philippines: 365 results from dedicated photo-ID and citizen science. Aquatic Conserv: Mar. Freshw. Ecosyst., 366 doi: 10.1002/aqc.2636.

367 Araujo G, Montgomery J, Pahang K, Labaja J, Murray R, Ponzo A. 2016b. Using minimally 368 invasive techniques to determine green sea turtle Chelonia mydas life-history parameters. Journal 369 of Experimental Marine Biology and Ecology; 483(2016):25-30.

370 Araujo G, Vivier F, Labaja J, Hartley D, Ponzo A. 2017. Assessing the impacts of tourism on the 371 world's largest fish Rhincodon typus at Panaon Island, Southern Leyte, Philippines. Aquatic 372 Conservation: Marine and Freshwater Ecosystems.

373 Arzoumanian Z, Holmberg J, Norman B. 2005. An astronomical pattern-matching algorithm for 374 computer-aided identification of whale sharks Rhincodon typus. Journal of Applied Ecology; 375 42(6):999-1011.

376 Berumen ML, Braun CD, Cochran JE, Skomal GB, Thorrold SR. 2014. Movement patterns of 377 juvenile whale sharks tagged at an aggregation site in the Red Sea. PLoS One; 9(7):e103536.

378 Brierley AS. Diel vertical migration. 2014. Current Biology; 24(22):R1074-6. 
379 Brunnschweiller JW, Baensch H, Pierce SJ, Sims DW. 2009. Deep-diving behaviour of a whale 380 shark (Rhincodon typus) during long-distance movement in the western Indian Ocean. J. Fish 381 Biol. 74, 706 - 714. (doi:10.1111/j.1095-8649.2008.02155.x)

382 Cabrera OC, Villanoy CL, David LT, Gordon AL. 2011. Barrier layer control of entrainment and 383 upwelling in the Bohol Sea, Philippines. Oceanography; 24(1):130-41.

384 Cagua EF, Cochran JE, Rohner CA, Prebble CE, Sinclair-Taylor TH, Pierce SJ, Berumen ML. 385 2015. Acoustic telemetry reveals cryptic residency of whale sharks. Biology Letters; 386 11(4):20150092.

387 Clingham E, Webb HD, de la Parra Venegas R, Schreiber C, Reid J, Pierce SJ, Hueter R, Hindle 388 K, Henry L, Beard A, Dove ADM. 2016. Further evidence of the importance of St. Helena as 389 habitat for whale sharks. QScience Proceedings 2016 2016, 2, 11.

390 Cochran JEM, Hardenstine RS, Braun CD, Skomal GB, Thorrold SR, Xu K, Genton MG, 391 Berumen ML. 2016. Population structure of a whale shark Rhincodon typus aggregation in the 392 Red Sea. J Fish Biol. doi:10.1111/jfb.13054

393 Douglas DC, Weinzierl R, C Davidson S, Kays R, Wikelski M, Bohrer G. 2012. Moderating 394 Argos location errors in animal tracking data. Methods in Ecology and Evolution; 3(6):999-1007.

395 Eckert SA \& Stewart BS. 2001. Telemetry and satellite tracking of whale sharks, Rhincodon 396 typus, in the Sea of Cortez, Mexico, and the north Pacific Ocean. Environmental Biology of 397 Fishes, 60(1-3), 299-308.

398 Eckert SA, Dolar LL, Kooyman GL, Perrin W, Rahman RA. 2002. Movements of whale sharks 399 (Rhincodon typus) in South-east Asian waters as determined by satellite telemetry. Journal of 400 Zoology; 257(1):111-5.

401 Gordon AL, Sprintall J, Ffield A. 2011. Regional oceanography of the Philippine Archipelago. 402 Oceanography, 24(1):14-27.

403 Graham RT, Roberts CM, Smart JC. 2006. Diving behaviour of whale sharks in relation to a 404 predictable food pulse. Journal of the Royal Society Interface; 3(6):109-16. 
405 Hearn AR, Green JR, Espinoza E, Peñaherrera C, Acuña D, Klimley AP. 2013. Simple criteria to 406 determine detachment point of towed satellite tags provide first evidence of return migrations of 407 whale sharks (Rhincodon typus) at the Galapagos Islands, Ecuador. Animal Biotelemetry; $4081(1): 11$.

409 Heupel MR, Carlson JK, Simpfendorfer CA. 2007. Shark nursery areas: concepts, definition, 410 characterization and assumptions. Marine Ecology Progress Series. May 14;337:287-97.

411 Hsu HH, Joung SJ, Liao YY, Liu KM. 2007. Satellite tracking of juvenile whale sharks, 412 Rhincodon typus, in the Northwestern Pacific. Fisheries Research; 84(1):25-31.

413 Lalli CM, Parsons TR. 1997. Biological Oceanography - An Introduction, Vol. Elsevier, Oxford, 414 UK

415 Motta PJ, Maslanka M, Hueter RE, Davis RL, De la Parra R, Mulvany SL, Habegger ML, 416 Strother JA, Mara KR, Gardiner JM, Tyminski JP. Feeding anatomy, filter-feeding rate, and diet 417 of whale sharks Rhincodon typus during surface ram filter feeding off the Yucatan Peninsula, 418 Mexico. Zoology. 2010 Aug 31;113(4):199-212.

419 Li W, Wang Y, Norman B. 2012. A preliminary survey of whale shark Rhincodon typus catch 420 and trade in China: an emerging crisis. Journal of Fish Biology; 80(5):1608-18.

421 Mendelssohn R. 2017. xtractomatic: Accessing Environmental Data from ERD's ERDDAP 422 Server. R package version 3.3.2 https://CRAN.R-project.org/package=xtractomatic 423 Norman BM, Reynolds S, Morgan DL. 2016. Does the whale shark aggregate along the Western 424 Australian coastline beyond Ningaloo Reef? Pacific Conservation Biology 22;22(1):72-80.

425 Norman BM, Holmberg JA, Arzoumanian Z, Reynolds SD, Wilson RP, Rob D, Pierce SJ, Gleiss 426 AC, de la Parra R, Galvan B, Ramirez-Macias D, Robinson D, Fox S, Graham R, Rowat D, 427 Potenski M, Levine M, Mckinney JA, Hoffmayer E, Dove ADM, Hueter R, Ponzo A, Araujo G, 428 Aca E, David D, Rees R, Duncan A, Rohner CA, Prebble CEM, Hearn A, Acuna D, Berumen 429 ML, Vázquez A, Green J, Bach SS, Schmidt JV, Beatty SJ, Morgan DL. 2017. Undersea 430 Constellations: The Global Biology of an Endangered Marine Megavertebrate Further Informed 431 through Citizen Science, 2017/11/29, BioScience, bix127.

432 Pierce SJ and Norman B. 2016. IUCN Red List Assessment for Whale Shark Rhincodon typus. 433 Accessed 28 $8^{\text {th }}$ September 2017. 
434 Ponzo A, Pahang K, Silberg J, Haskins G, Emata CL, Acebes JM. 2011. Presence and 435 distribution of cetaceans in the northeastern Bohol Sea. In 19th Biennial Conference on the 436 Biology of Marine Mammals, FL: Tampa 2011.

437 Quimbayo JP, Dias MS, Schlickmann OR, Mendes TC. 2017. Fish cleaning interactions on a 438 remote island in the Tropical Eastern Pacific. Marine Biodiversity; 47(2):603-8.

439 Quimpo FT. 2013. Sea turtles of Macajalar and Gingoog Bays Mindanao, Philippines. Asian 440 Journal of Biodiversity; 4(169):e189.

441 Rambahiniarison JM, Araujo G, Lamoste MJ, Labaja J, Snow S, Ponzo A. 2016. First records of 442 the reef manta ray Manta alfredi in the Bohol Sea, Philippines, and its implication for 443 conservation. Journal of Asia-Pacific Biodiversity; 9(4):489-93.

444 Ramírez-Macías D, Queiroz N, Pierce SJ, Humphries NE, Sims DW, Brunnschweiler JM. 2017. 445 Oceanic adults, coastal juveniles: tracking the habitat use of whale sharks off the Pacific coast of 446 Mexico. PeerJ; 5:e3271.

447 Robinson DP, Jaidah MY, Bach S, Lee K, Jabado RW, Rohner CA, March A, Caprodossi S, 448 Henderson AC, Mair JM, Ormond R. 2016. Population Structure, Abundance and Movement of 449 Whale Sharks in the Arabian Gulf and the Gulf of Oman. PloS One; 11(6):e0158593.

450 Robinson DP, Jaidah MY, Bach SS, Rohner CA, Jabado RW, Ormond R, Pierce SJ. 2017 Some 451 like it hot: Repeat migration and residency of whale sharks within an extreme natural 452 environment. PloS One; 12(9):e0185360.

453 Rohner CA, Couturier LI, Richardson AJ, Pierce SJ, Prebble CE, Gibbons MJ, Nichols PD. 454 2013. Diet of whale sharks Rhincodon typus inferred from stomach content and signature fatty 455 acid analyses. Marine Ecology Progress Series: 493:219-35.

456 Rohner CA, Armstrong AJ, Pierce SJ, Prebble CE, Cagua EF, Cochran JE, Richardson AJ. 2015. 457 Whale sharks target dense prey patches of sergestid shrimp off Tanzania. Journal of plankton 458 research, fbv010.

459 Rohner CA, Burgess KB, Rambahiniarison JM, Stewart JD, Ponzo A, Richardson AJ. 2017. 460 Mobulid rays feed on euphausiids in the Bohol Sea. Royal Society Open Science: 4(5):161060. 
461 Rohner CA, Jaine FRA, Pierce SJ, Bennett MB, Weeks SJ, Richardson AJ. 2018. Movement

462 ecology of whale sharks in the Southern Mozambique Channel. PeerJ 4161.

463 Rowat D \& Brooks KS. 2012. A review of the biology, fisheries and conservation of the whale 464 shark Rhincodon typus. Journal of fish biology, 80(5), 1019-1056.

465 Rowat D \& Gore M. 2007. Regional scale horizontal and local scale vertical movements of

466 whale sharks in the Indian Ocean off Seychelles. Fisheries Research 84:32-40

467 Simpfendorfer CA \& Dulvy NK. 2017. Bright spots of sustainable shark fishing. Current 468 Biology; 6;27(3):R97-8.

469 Secretariat CTI. Regional Plan of Action: Coral Triangle Initiative on Coral Reefs, Fisheries and 470 Food Security (CTI-CFF). Mondano, Indonesia. 2009.

471 Stewart JD, Rohner CA, Araujo G, Avila J, Fernando D, Forsberg K, Ponzo A, Rambahiniarison 472 J, Kurle C, Semmens BX. 2017. Trophic overlap in mobulid rays: insights from stable isotope 473 analysis. Marine Ecology Progress Series.

474 Thomson JA, Araujo G, Labaja JJ, McCoy E, Murray R, Ponzo A. 2017. Feeding the world's 475 largest fish: highly variable whale shark residency patterns at a provisioning site in the 476 Philippines. Royal Society Open Science.

477 Tyminski JP, de la Parra-Venegas R, Cano JG, Hueter RE. 2015. Vertical Movements and 478 Patterns in Diving Behavior of Whale Sharks as Revealed by Pop-Up Satellite Tags in the 479 Eastern Gulf of Mexico. PloS One; 10(11), e0142156.

480 Van Tienhoven AM, Den Hartog JE, Reijns RA, Peddemors VM. 2007. A computer-aided 481 program for pattern-matching of natural marks on the spotted raggedtooth shark Carcharias 482 taurus. Journal of Applied Ecology; 44(2):273-80.

483 Vignaud TM, Maynard JA, Leblois R, Meekan MG, Vázquez-Juárez R, Ramírez-Macías D, 484 Pierce SJ, Rowat D, Berumen ML, Beeravolu C, Baksay S. 2014. Genetic structure of 485 populations of whale sharks among ocean basins and evidence for their historic rise and recent 486 decline. Molecular ecology ;23(10):2590-601. 


\section{Table $\mathbf{1}$ (on next page)}

Satellite tracking details for all 17 whale sharks tagged in the Sulu and Bohol Seas, Philippines.

Satellite track details, with tag number, shark ID ( www.whaleshark.org ), sex, estimated total length (TL), deployment and last transmission dates, tracking duration, number of transmitting days, overall track distance, mean speed and the number of positions per transmitting day. 
1 Table 1: Satellite track details, with tag number, shark ID (www.whaleshark.org), sex, estimated total length (TL), deployment and last

2 transmission dates, tracking duration, number of transmitting days, overall track distance, mean speed and the number of positions per

3 transmitting day.

\begin{tabular}{|c|c|c|c|c|c|c|c|c|c|c|c|}
\hline Tag & Shark & Sex & $\begin{array}{c}\mathrm{TL} \\
(\mathrm{cm})\end{array}$ & Location & $\begin{array}{c}\text { Deployment } \\
\text { date }\end{array}$ & Last location & $\begin{array}{c}\text { Tracking } \\
\text { duration (d) }\end{array}$ & $\begin{array}{c}\text { Transmitting } \\
\text { days }\end{array}$ & $\begin{array}{c}\text { Distance } \\
(\mathbf{k m})\end{array}$ & $\begin{array}{c}\text { Speed } \\
\left(\mathbf{k m ~ d}^{-1}\right)\end{array}$ & $\begin{array}{c}\text { Positions per } \\
\text { transmitting } \\
\text { day }\end{array}$ \\
\hline 142218 & P-904 & $\mathrm{M}$ & 450 & $\begin{array}{c}\text { Panaon } \\
\text { Island }\end{array}$ & 17-Nov-15 & 03-Mar-16 & 108 & 60 & 1538 & 14.2 & 2.3 \\
\hline 142219 & P-970 & $\mathrm{F}$ & 650 & Mindanao & $07-A p r-16$ & 23-Jun-16 & 78 & 42 & 1661 & 21.3 & 2.2 \\
\hline 142220 & P-905 & $\mathrm{M}$ & 500 & $\begin{array}{c}\text { Panaon } \\
\text { Island }\end{array}$ & 18-Nov-15 & 01-Mar-16 & 105 & 38 & 2580 & 24.6 & 2.4 \\
\hline 142222 & P-791 & $\mathrm{M}$ & 600 & Mindanao & 07-Apr-16 & 24-May-16 & 48 & 24 & 459 & 9.6 & 2.8 \\
\hline 142224 & P-955 & $\mathrm{F}$ & 700 & Mindanao & 19-Mar-16 & 01-May-16 & 44 & 12 & 314 & 7.1 & 2.3 \\
\hline 142225 & P-818 & $\mathrm{M}$ & 550 & TRNP & 22-May-15 & 03-Sep-15 & 105 & 45 & 2024 & 19.3 & 2.4 \\
\hline 142227 & P-971 & $\mathrm{M}$ & 450 & Mindanao & 07-Apr-16 & 29-Apr-16 & 23 & 17 & 309 & 13.4 & 2.4 \\
\hline 142228 & P-926 & $\mathrm{M}$ & 500 & Mindanao & 19-Mar-16 & 17-Jun-16 & 91 & 28 & 426 & 4.7 & 2.5 \\
\hline 142229 & P-909 & UK & 550 & $\begin{array}{c}\text { Panaon } \\
\text { Island }\end{array}$ & 18-Nov-15 & 12-Jan-16 & 56 & 20 & 178 & 3.2 & 1.9 \\
\hline 142231 & P-821 & $\mathrm{M}$ & 600 & TRNP & 23-May-15 & 28-Jul-15 & 67 & 49 & 2320 & 34.6 & 2.8 \\
\hline 142232 & P-430 & $\mathrm{M}$ & 550 & $\begin{array}{l}\text { Panaon } \\
\text { Island }\end{array}$ & 10-Apr-15 & 01-Jun-15 & 53 & 9 & 149 & 2.8 & 1.0 \\
\hline 142233 & P-493 & $\mathrm{M}$ & 500 & $\begin{array}{l}\text { Panaon } \\
\text { Island }\end{array}$ & 09-Apr-15 & 17-Jun-15 & 70 & 15 & 472 & 6.7 & 2.6 \\
\hline 142235 & P-813 & $\mathrm{F}$ & 450 & TRNP & 17-May-15 & 14-Jul-15 & 59 & 22 & 1493 & 25.3 & 2.6 \\
\hline 142236 & P-814 & UK & 600 & TRNP & 17-May-15 & 01-Jun-15 & 16 & 14 & 764 & 47.8 & 2.5 \\
\hline 142237 & P-816 & M & 550 & TRNP & 20-May-15 & 25-May-15 & 6 & 3 & 145 & 24.2 & 1.7 \\
\hline 142238 & P-491 & $\mathrm{M}$ & 600 & $\begin{array}{c}\text { Panaon } \\
\text { Island }\end{array}$ & 24-Nov-15 & 28-Mar-16 & 126 & 12 & 163 & 1.3 & 2.2 \\
\hline
\end{tabular}




\begin{tabular}{|c|c|c|c|c|c|r|r|r|c|c|c|}
\hline 142239 & P-532 & $\mathrm{F}$ & 600 & $\begin{array}{c}\text { Panaon } \\
\text { Island }\end{array}$ & 16-Nov-15 & 14-Dec-15 & 29 & 11 & 86 & 3.0 & 1.6 \\
\hline & & & & & & Maximum & 126 & 60 & 2580 & 47.8 & 2.8 \\
\hline & & & & & & Minimum & 6 & 3 & 86 & 1.3 & 1.0 \\
\hline & & & & & & Mean & 63.76 & 24.76 & 887.12 & 15.5 & 2.2 \\
\hline & & & & & & S.D. & 34.96 & 16.32 & 851.90 & 13.0 & 0.5 \\
\hline
\end{tabular}




\section{Table 2 (on next page)}

Tagging location and resightings across different sites in the Sulu and Bohol Seas, as confirmed through photo-ID.

*From citizen science. 
1 Table 2: Tagging location and resightings across different sites in the Sulu and Bohol Seas.

$2 *$ From citizen science

\begin{tabular}{|c|c|c|c|c|c|c|}
\hline $\begin{array}{l}\text { Shark } \\
\text { ID }\end{array}$ & $\begin{array}{ll}\text { Date } & 1^{\text {st }} \\
\text { identified } & \end{array}$ & $\begin{array}{l}\text { Location } \\
1^{\text {st }} \\
\text { identified }\end{array}$ & $\begin{array}{l}\text { Date of } \\
\text { tagging }\end{array}$ & $\begin{array}{l}\text { Location of } \\
\text { tagging }\end{array}$ & $\begin{array}{l}\text { Last date } \\
\text { sighted }\end{array}$ & $\begin{array}{l}\text { Location } \\
\text { last sighted }\end{array}$ \\
\hline P-904 & 17-Nov-15 & $\begin{array}{l}\text { Panaon } \\
\text { Island }\end{array}$ & 17-Nov-15 & $\begin{array}{l}\text { Panaon } \\
\text { Island }\end{array}$ & & \\
\hline P-970 & 07-Apr-16 & Mindanao & $07-A p r-16$ & Mindanao & & \\
\hline P-905 & 18-Nov-15 & $\begin{array}{l}\text { Panaon } \\
\text { Island }\end{array}$ & 18-Nov-15 & $\begin{array}{l}\text { Panaon } \\
\text { Island }\end{array}$ & 20-Dec-15 & $\begin{array}{l}\text { Panaon } \\
\text { Island }\end{array}$ \\
\hline P-791 & 25-Mar-15 & $\begin{array}{l}\text { Panaon } \\
\text { Island }\end{array}$ & 07-Apr-16 & Mindanao & & \\
\hline P-955 & 19-Mar-16 & Mindanao & 19-Mar-16 & Mindanao & & \\
\hline P-818 & 22-May-15 & TRNP & 22-May-15 & TRNP & & \\
\hline P-971 & 07-Apr-16 & Mindanao & 07-Apr-16 & Mindanao & & \\
\hline P-926 & 07-Dec-15 & $\begin{array}{l}\text { Panaon } \\
\text { Island }\end{array}$ & 19-Mar-16 & Mindanao & & \\
\hline P-909 & 18-Nov-15 & $\begin{array}{l}\text { Panaon } \\
\text { Island }\end{array}$ & 18-Nov-15 & $\begin{array}{l}\text { Panaon } \\
\text { Island }\end{array}$ & & \\
\hline P-821 & 23-May-15 & TRNP & 23-May-15 & TRNP & & \\
\hline P-430 & 03-May-12 & $\begin{array}{l}\text { Oslob, } \\
\text { Cebu }\end{array}$ & 10-Apr-15 & $\begin{array}{l}\text { Panaon } \\
\text { Island }\end{array}$ & 30-Nov-17 & $\begin{array}{l}\text { Panaon } \\
\text { Island }\end{array}$ \\
\hline P-493 & 28-Feb-13 & $\begin{array}{l}\text { Panaon } \\
\text { Island }\end{array}$ & 09-Apr-15 & $\begin{array}{l}\text { Panaon } \\
\text { Island }\end{array}$ & 02-Jan-16 & $\begin{array}{l}\text { Panaon } \\
\text { Island }\end{array}$ \\
\hline P-813 & 17-May-15 & TRNP & 17-May-15 & TRNP & 18-May-15 & TRNP* \\
\hline P-814 & 17-May-15 & TRNP & 17-May-15 & TRNP & & \\
\hline P-816 & 20-May-15 & TRNP & 20-May-15 & TRNP & & \\
\hline
\end{tabular}




\begin{tabular}{|l|l|l|l|l|l|l|}
\hline P-491 & 25-Feb-13 & $\begin{array}{l}\text { Panaon } \\
\text { Island }\end{array}$ & 24-Nov-15 & $\begin{array}{l}\text { Panaon } \\
\text { Island }\end{array}$ & 03-Dec-15 & $\begin{array}{l}\text { Panaon } \\
\text { Island }\end{array}$ \\
\hline P-532 & 07-Apr-13 & $\begin{array}{l}\text { Panaon } \\
\text { Island }\end{array}$ & 16-Nov-15 & $\begin{array}{l}\text { Panaon } \\
\text { Island }\end{array}$ & 10-Jan-16 & $\begin{array}{l}\text { Panaon } \\
\text { Island }\end{array}$ \\
\hline
\end{tabular}

3 
Figure 1

Tracks of whale sharks tagged in Panaon Island, Southern Leyte.

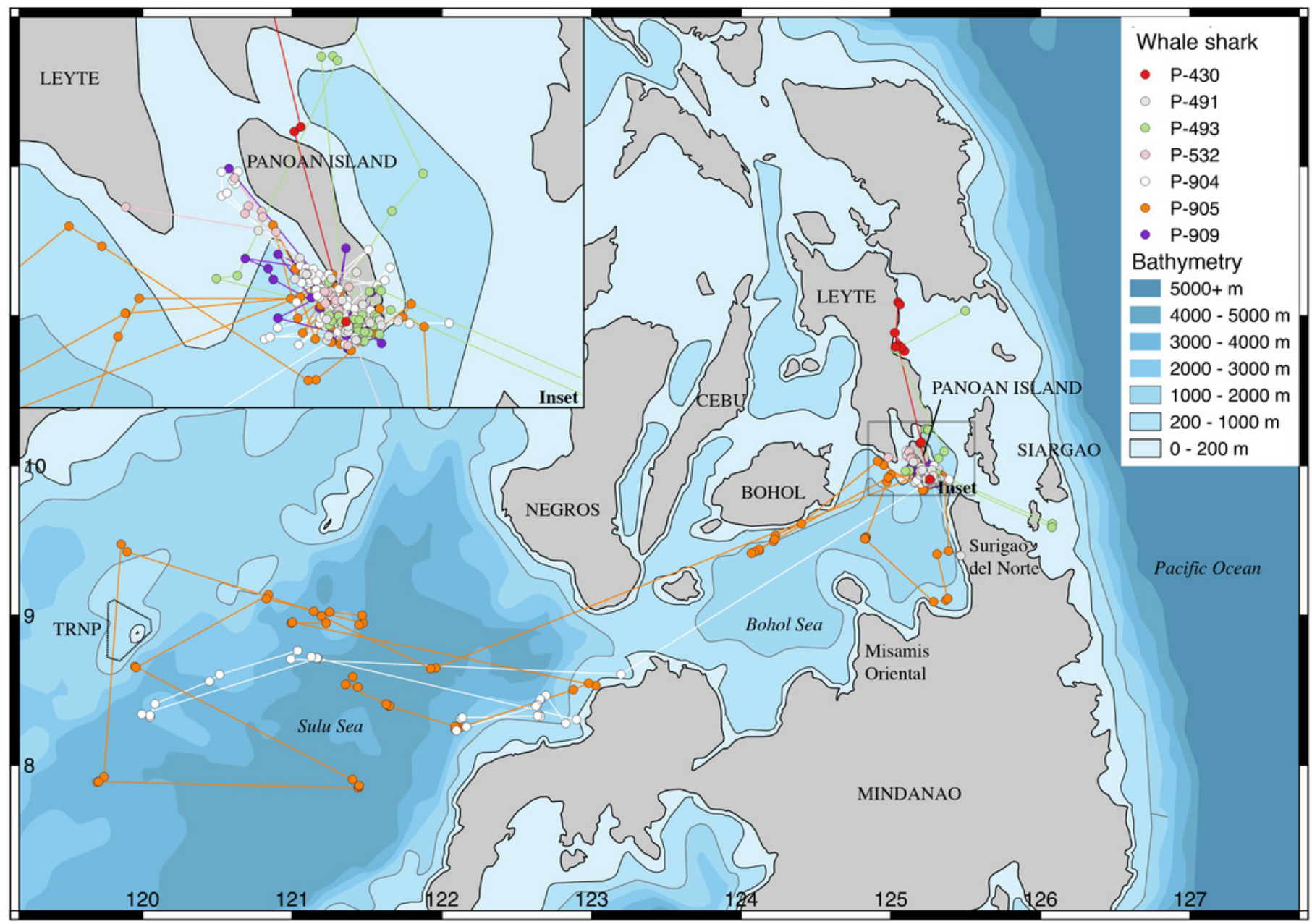


Figure 2

Tracks of whale sharks tagged in Surigao del Norte and Misamis Oriental, Mindanao.

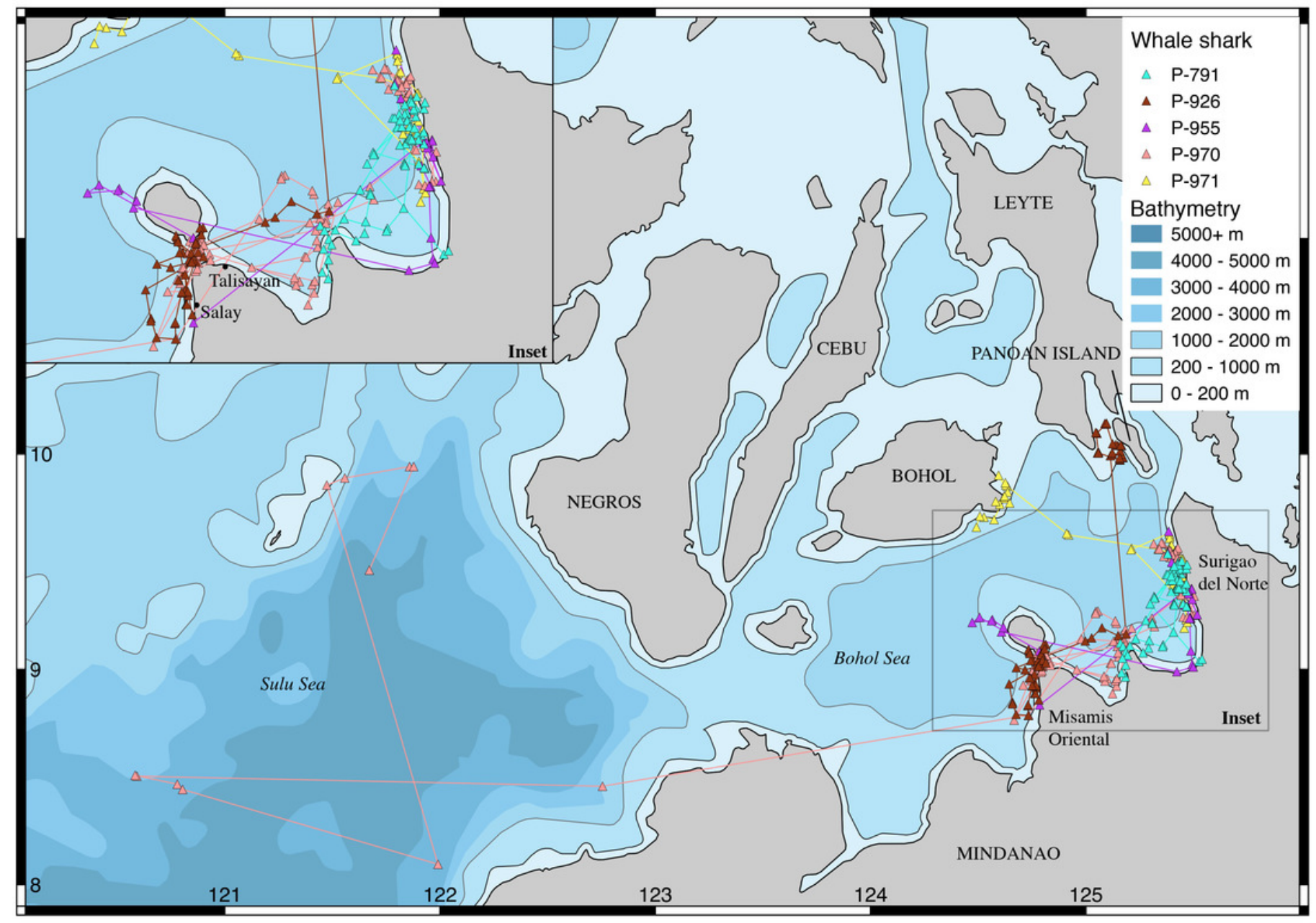


Figure 3

Tracks of whale sharks tagged in Tubbataha Reefs Natural Park, with park boundaries in orange.

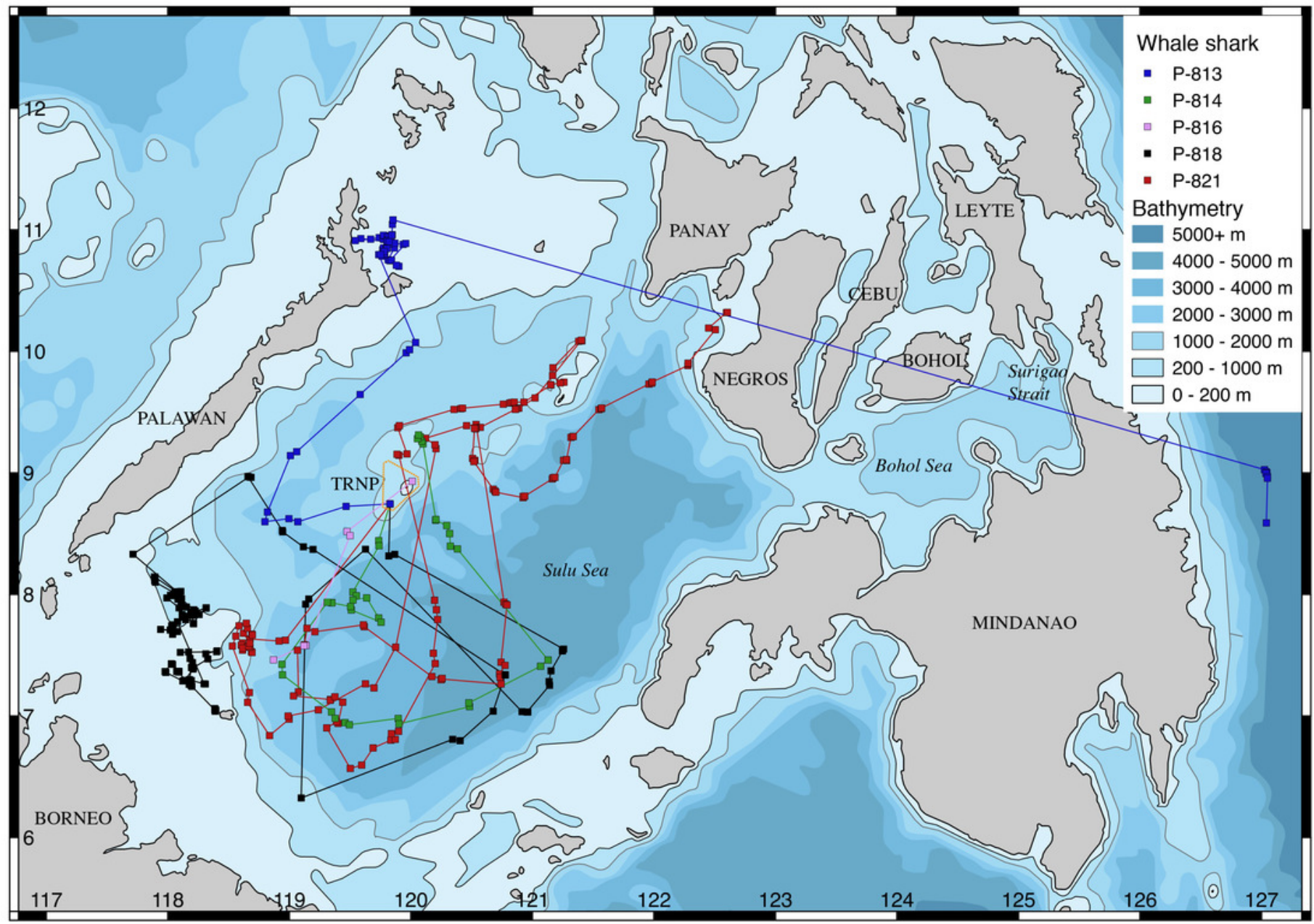


Figure 4(on next page)

Time-at-temperature histograms for all whale shark tags combined, with (a) Overall results, (b) Daytime observations (6am-6pm) and (c) Night-time observations. 


\section{Figure 5}

Time-at-temperature time-series for shark P-818 that was tagged in TRNP and spent its entire track within the Sulu Sea.

(A) is the entire histogram data, with a chronological $x$-axis, $(B)$ has a continuous $x$-axis to illustrate the gaps in TAT data, (C) are all histograms from the daytime, and (D) are all histograms from the night-time.
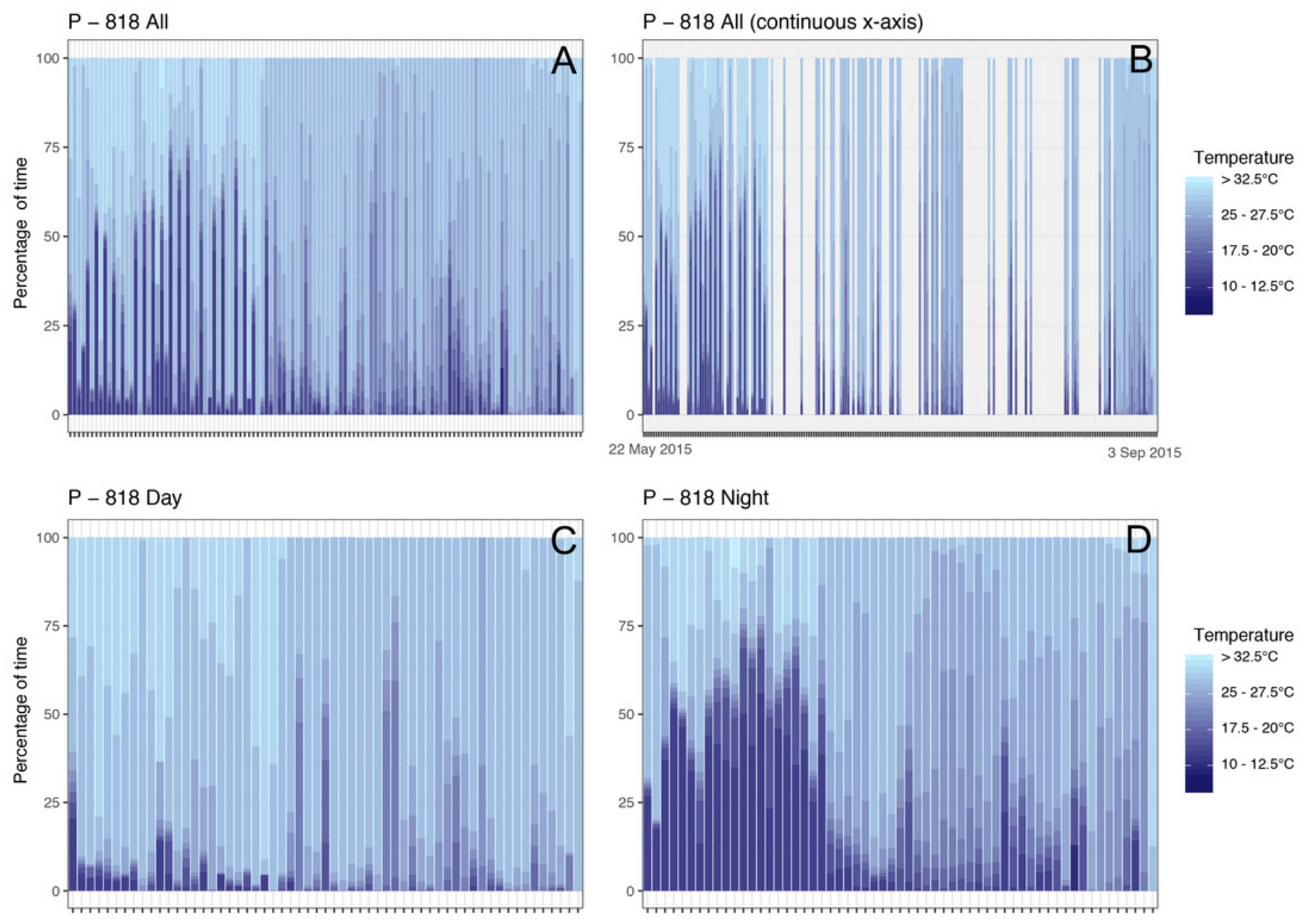